\title{
Modeling and simulation of watershed erosion: Case study of Latian dam watershed
}

\author{
Mirzai M.. ${ }^{*}$ Sajadi A. and Nazari A. \\ Water- Energy Research Center-Sharif, Iran. \\ Received 20 May 2013; Accepted 11 March, 2014
}

\begin{abstract}
The Latian Dam is one of the important drinking water resources of Tehran, and it also has a role in preventing the flood. It is very important to keep the quality of water and preventing the dam from filling. Considering the special aspects of RUSLE model, it was used for estimating the amount of erosion in the watershed of dam including the sub-basins: Jajrood River, Kond River and Afjeh River, and then compared with the actual values measured. The results of modeling show that the degree of erosion is high because of steep slopes, lack of plant coverage. The results of modeling the amount of erosion in The Jajrood basin have been estimated about 1,524 ton/year, in Kond basin about 228.5 ton/ year, and in the Afjeh basin about 103.1 ton/year. By using the results of the water samples analyses, the amount of phosphorus entering the reservoir by the rivers were calculated. This research shows that, by using the proper coverage in the basin, the amount of sediment and phosphorus entering the reservoir, decreases considerably.
\end{abstract}

Key words: Latian Dam, phosphorus, reservoir.

\section{INTRODUCTION}

Soil erosion can cause ecological changes in the region. With regard to the role of planning and study of human and natural changes in erosion, assessment and adaptation model applied to each region, it is important. Latian Dam watershed is one of the areas where soil erosion is serious; the study of soil erosion in the area, as one of the water sources of Tehran is very important, particular area, population expansion, land use changed faces (Water and Energy Center of Sharif University, 2003a). Human sewage entering the river increased risk of erosion and sedimentation, pollution and nutrients in the reservoir. Including research done in this area;
Quantitative modeling of soil erosion using AHP (Analytic hierarchy process) in the watershed Latian (Maleki et al., 2011), evaluate the accuracy and efficiency of computer models II SEDIMOT in estimating runoff and sediment (Sadeghi, 1994), and the application and model evaluation M.P.S.I.A.C. Using satellite imagery, geographic information systems (GIS) in the sub-basin Lavarak (Tahmasebipoor, 1995) and comparison of models RUSLE and SWAT to estimate Erosions in the sub-basin Amameh (Poorabdollah, 2007). In this study, RUSLE model helping GIS system for modeling soil erosion in the watershed Latian was used. And modeling results are

*Corresponding author. E-mail: mirzai@sharif.edu

Author(s) agree that this article remain permanently open access under the terms of the Creative Commons Attribution License 4.0 International License 
Table 1. The data used in the model.

\begin{tabular}{lll}
\hline S/N & Model inputs & Applied data \\
\hline 1 & Slope steepness and slope length & GIS map 1:50,000 Scale \\
2 & Rainfall erosivity & Rainfall intensity got from Tehran's Regional Water Organization for 2 years \\
3 & Meteorology & Temperature and rainfall Values at the different sub-basins \\
4 & Soil erodibility & $\begin{array}{l}\text { The soil map }(1: 50,000), \text { separate reports including: the percentage of silt, } \\
\text { sand, organic materials, soil structure and soil. }\end{array}$ \\
& & $\begin{array}{l}1: 50,000 \text { maps containing the layers of orchards, pastures and farmlands } \\
\text { with the related reports from Iranian National Geography Organization }\end{array}$ \\
\hline
\end{tabular}

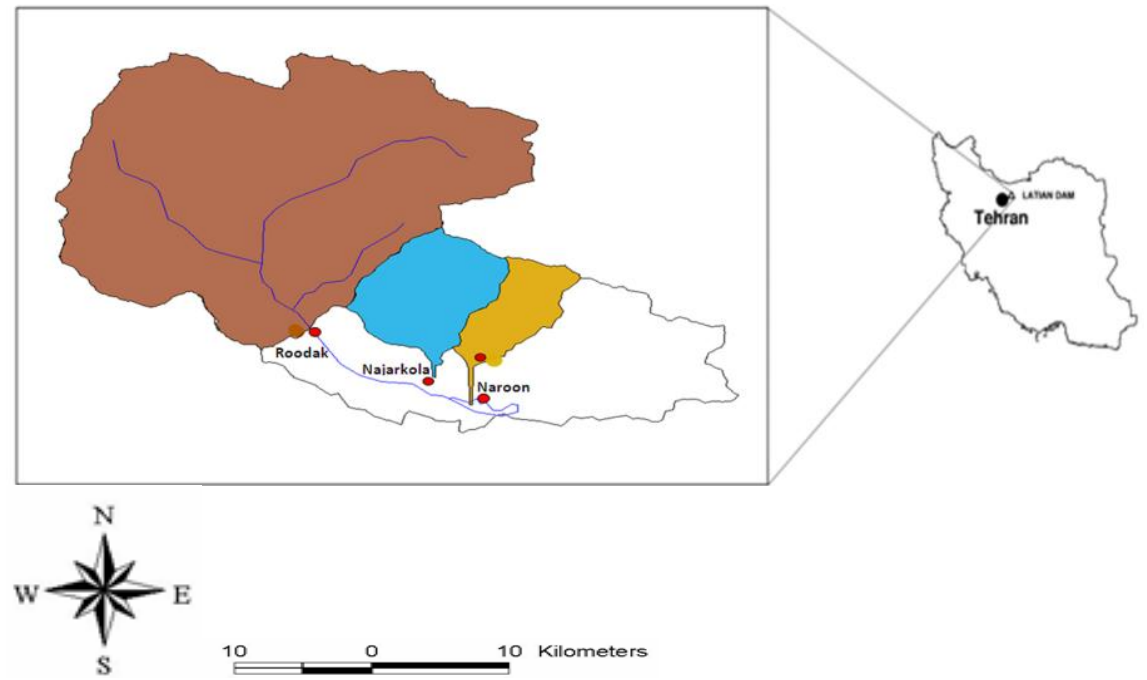

Figure 1. The location of stations and their upstream sub-basins.

compared with the actual values measured. The application of the RUSLE model has some advantages: (i) the data required are not very complex or unavailable in a developing country; (ii) this model is compatible properly with GIS software (Blonn, 2001), (iii) the use of this model is simplified by the presence of a graphical environment. Using this model with GIS information in raster format, the potential erosion can be found in any cell (Cox and Madramootoo, 1998). Also in regards to land use, based on management decisions, simulated erosion and its impact on the amount of sediment and phosphorus transport into the reservoir is shown. Study and modeling of the sub-basin Jajrood, and sub-basins kond and Afjeh is performed.

\section{METHODS AND MATERIALS}

The base equation of RUSLE model is as follows (Yazidhi, 2003):

$$
A=L S \times R \times K \times C \times P
$$

Where: $\mathrm{A}=$ the average annual soil loss (ton/ha/year); $\mathrm{LS}=$ the combination of the slope steepness and slope length (the factor without dimension); $\mathrm{R}=$ the rainfall erosivity factor; $\mathrm{K}=$ the factor of soil erodibility; $\mathrm{C}=$ the coefficient of plant coverage, and $\mathrm{P}=$ the coefficient of support practice.

The definition and application of every one of the above mentioned coefficients have been presented (Wischmeier and Smith, 1978; Desmet and Govers, 1996; Wischmeier et al., 1971).

The collected information about the watershed of Latian Dam is shown in Table 1. These stations together with their upstream subbasins are shown in the Figure 1 and characterized in Table 2.

\section{Input data}

Figure 2 shows map of the river and its subdivisions, watershed boundaries and sub basins. Figure 3 shows the digital elevation map of the watershed (DEM) and the average slope values for each region. Figure 4 shows the type of vegetation in the watershed. Coefficients related to the vegetation which should be used in RUSLE model are shown in Table 3 and the values have been obtained from studies conducted in the region (Tehran's Agricultural Organization, 2002a). 
Table 2. The specifications of measuring stations in the watershed of Latian dam.

\begin{tabular}{lllllll}
\hline Basin area $\left(\mathbf{k m}^{2}\right)$ & Sub-Basin & Elevation $\mathbf{( m )}$ & Latitude & Longitude & River & Station \\
\hline 403 & Garmabdar, Meygoon, Ahar, & 1700 & $35-53$ & $51-32$ & Jajrood & Roodak \\
& Emameh and Roodak & & & & & \\
58 & Kond & 1670 & $35-49$ & $51-38$ & Kond & Najarkola \\
31 & Afjeh & 1790 & $35-50$ & $51-40$ & Afjeh & Naroon \\
\hline
\end{tabular}

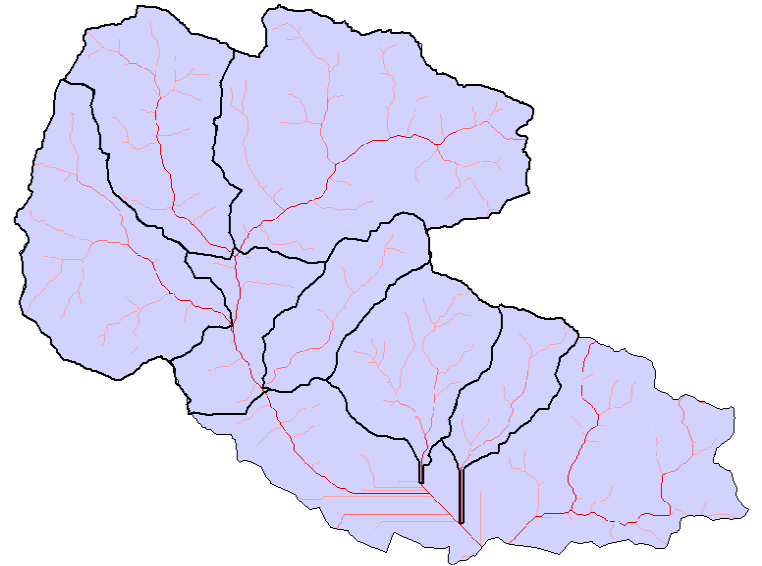

Figure 2. Distinguishing the boundaries of sub-basins with the help of arc view.

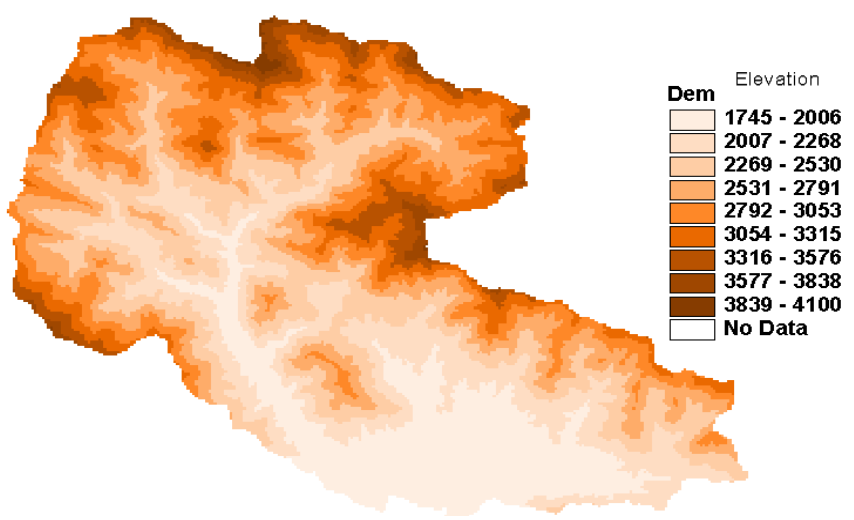

Figure 3. The DEM of the Latian Dam watershed.

The necessary inputs for the RUSLE model are: Average monthly temperature, the average amount of rainfall in month, the erosivity factor $(R)$ and were obtained by studying the measured data in the stations (Tehran's Agricultural Organization, 2002b).

Soil types in this area include: Loamy, sandy loam, and clay loam. Types of Watershed soils are: 1 - Mountains; 2-hills; 3- flats and upper terraces; 4- Plains. Watershed land units, as part of the soil types are mentioned and Have the same physical characteristics, as of $1.1,1.2,1.3,1.4,2.1,2.2,3.1,4.1$ as shown in Figure 5 (Water and Energy center of Sharif University, 2003b).

The existing hydrological groups are shown in Table 4.

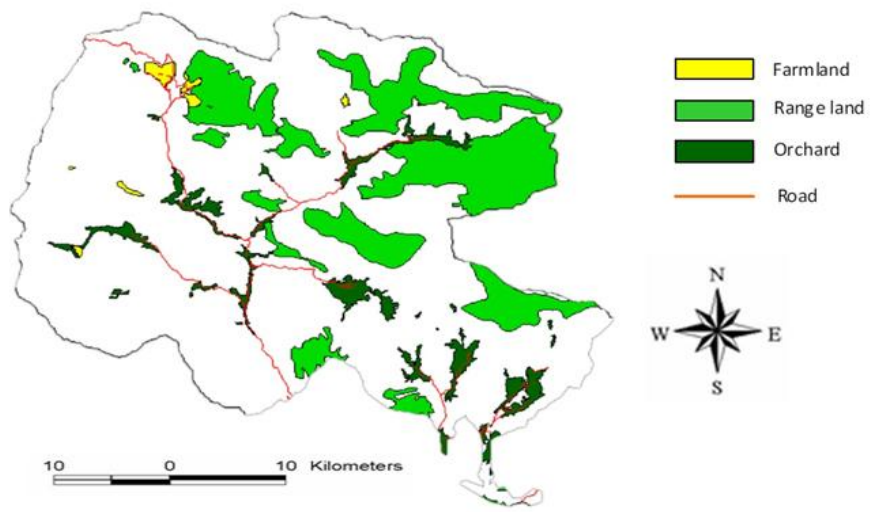

Figure 4. The map of plant.

\section{RESULTS AND DISCUSSION}

The amounts of erosion, obtained from the model for any type of soil and any type of Land cover were presented for every sub-basin in Table 5 . So, the whole amount of erosion per year in the basins of Roodak, Afjeh and Kond can be calculated by adding up the results of erosion in their sub-basins.

Due to the global equation erosion between any two regions with similar characteristics, whatever the place, the slope is greater or less vegetation or soil permeability is less, The amount of erosion in the area further. The result shows due to high slope and low vegetation in most areas, soil erosion is high.

\section{Comparison with actual amounts and determining the model precision}

A part of the eroded soil is transferred to downstream area by the flowing water in the form of sediment. This proportion is defined in the following way:

Sediment delivery ratio $(\mathrm{SDR})=\frac{\text { The amount of sediment delivered to a point }}{\text { The amount of eroded soil at upstream of the point }}$

To determine SDR and estimation of suspended load, the formulas proposed in this regard has been used (Foster, 2003). 
Table 3. RUSLE input parameters for plant coverage.

\begin{tabular}{lccllc}
\hline Kind of plants & Canopy cover $(\%)$ & Falling height $(\mathbf{m})$ & Residue & Canopy shape & Rock cover \\
\hline Range land & 50 & 0.2 & Range litter & Rectangle & 30 \\
Farmland & 30 & 0.3 & The roots and branch residue & Rectangle & 30 \\
Orchard & 35 & 2.1 & Bushes and branches and leaves & Rectangle & 30 \\
barren land & - & - & - & - & 30 \\
\hline
\end{tabular}

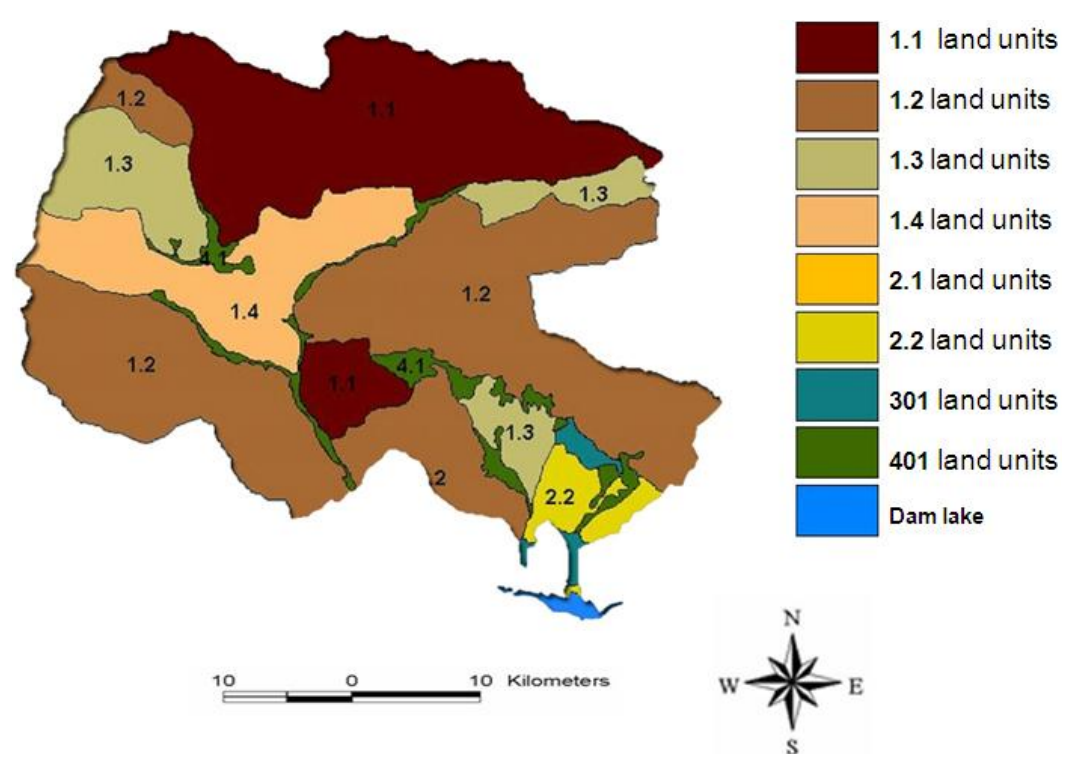

Figure 5. The map of evaluating the sources and the capability

Table 4. Hydrological groups of soil in the Latian Dam watershed.

\begin{tabular}{ccl}
\hline Hydrological group & Minimum permeability $\mathbf{( c m} / \mathbf{h})$ & Runoff generation potential \\
\hline A & $7.5-11.5$ & Low \\
B & $3.5-7.5$ & Low to moderate \\
C & $1.5-3.5$ & Relatively high \\
D & $<1.5$ & High \\
\hline
\end{tabular}

The summary of the results (Including sediment calculated values and measured values and Model precision) are shown in Table 6.

\section{Estimating the phosphorus load entering the water due to erosion}

Total phosphate in the water consists of dissolved phosphorus and particulate phosphorus. The phosphorus existing in the sediments from soil erosion is particulate phosphorus. The amount of phosphorus in the unit of suspended sediment load is calculated from dividing particulate phosphorus load by suspended sediment load. This amount can be used for estimating the particulate phosphorus load entering the water after using the management procedures for preventing the erosion (the change of land-use) and investigating the change of the amount of phosphorus using these procedures. For calculating the phosphorus load, the results of the tests done by Sharif University of Technology were used. Figure 6 shows the variation of phosphorus-discharge at the mentioned stations.

The amounts of particulate phosphorus are shown in Table 7 based on the results of existing data. 
Table 5. The results of erosion modeling in the sub-basins.

\begin{tabular}{|c|c|c|c|c|c|c|c|}
\hline Sub-basin & $\begin{array}{l}\text { The type of } \\
\text { soil }\end{array}$ & $\begin{array}{l}\text { Permeability } \\
\text { (cm/h) }\end{array}$ & $\begin{array}{l}\text { Land } \\
\text { cover }\end{array}$ & $\begin{array}{c}\text { Slope } \\
\text { (degree) }\end{array}$ & $\begin{array}{l}\text { Area } \\
\left(\mathrm{km}^{2}\right)\end{array}$ & $\begin{array}{c}\text { Erosion (ton/ } \\
\mathrm{km}^{2} / \text { year) }\end{array}$ & $\begin{array}{c}\text { Erosion } \\
\text { (ton/year) }\end{array}$ \\
\hline \multirow[t]{13}{*}{ Garmabdar } & $\mathrm{SL}(1.1)$ & 1.5 & $P$ & 23.7 & 25.8 & 3362 & 86833 \\
\hline & & & F-L & 23.6 & 0.173 & 425.8 & 73.67 \\
\hline & & & B-L & 26.7 & 52.8 & 4482 & 236844 \\
\hline & $L(1.3)$ & 5.5 & $P$ & 22.2 & 10.0 & 3138 & 31376 \\
\hline & & & 0 & 16.4 & 1.16 & 2465 & 2860 \\
\hline & & & B-L & 19.8 & 3.49 & 3138 & 10950 \\
\hline & L (1.2) & 2.5 & $\mathrm{P}$ & 23.7 & 23.6 & 3810 & 89953 \\
\hline & & & B-L & 26.2 & 19.4 & 4931 & 95701 \\
\hline & SL (4.1) & 5.5 & O & 18.1 & 0.76 & 2241 & 1703 \\
\hline & & & B-L & 17.7 & 1.52 & 2241 & 3407 \\
\hline & SL (1.4) & 2.5 & 0 & 15.8 & 0.871 & 2465 & 2147 \\
\hline & & & $B-L$ & 22.6 & 15.4 & 3586 & 55093 \\
\hline & & & $P$ & 27.9 & 2.75 & 3810 & 10481 \\
\hline \multirow[t]{13}{*}{ Meygoon } & SL (1.1) & 1.5 & F-L & 18.3 & 1.94 & 336.2 & 650.8 \\
\hline & & & $P$ & 20.3 & 8.50 & 2913 & 24773 \\
\hline & & & B-L & 25.7 & 21.5 & 4482 & 96531 \\
\hline & $\mathrm{L}(1.2)$ & 2.5 & F-L & 20.7 & 0.331 & 358.6 & 118.7 \\
\hline & & & $P$ & 14.2 & 0.217 & 1860 & 403.7 \\
\hline & & & B-L & 21.9 & 8.19 & 3586 & 29350 \\
\hline & $L(1.3)$ & 5.5 & B-L & 24.8 & 18.4 & 3362 & 61822 \\
\hline & & & 0 & 18.5 & 0.600 & 2465 & 1479 \\
\hline & SL (4.1) & 5.5 & B-L & 18.4 & 1.96 & 2465 & 4832 \\
\hline & & & 0 & 11.5 & 1.23 & 1345 & 1655 \\
\hline & SL (1.4) & 2.5 & 0 & 18.5 & 0.917 & 2914 & 2672 \\
\hline & & & F-L & 24.6 & 0.283 & 403.4 & 114.2 \\
\hline & & & B-L & 25.0 & 12.6 & 3810 & 48173 \\
\hline \multirow[t]{8}{*}{ Ahar } & $L(1.3)$ & 4 & $B-L$ & 27.8 & 10.2 & 3810 & 38679 \\
\hline & SL (1.4) & 5.5 & B-L & 25.2 & 24.7 & 3362 & 83169 \\
\hline & & & F-L & 20.7 & 0.041 & 448.2 & 18.38 \\
\hline & SL (4.1) & 5.5 & B-L & 19.1 & 1.57 & 2465 & 3878 \\
\hline & & & 0 & 13.2 & 0.520 & 1569 & 815.8 \\
\hline & $L(1.2)$ & 2.5 & 0 & 14.8 & 1.76 & 2241 & 3940 \\
\hline & & & F-L & 10.4 & 0.162 & 269 & 43.57 \\
\hline & & & B-L & 23.9 & 55.2 & 3810 & 21085 \\
\hline \multirow[t]{10}{*}{ Roodak } & SL (1.4) & 2.5 & 0 & 11.1 & 0.612 & 1591 & 973.8 \\
\hline & & & B-L & 22.0 & 4.78 & 3586 & 17155 \\
\hline & SL (4.1) & 5.5 & 0 & 10.4 & 0.290 & 1233 & 357.5 \\
\hline & & & B-L & 22.4 & 1.79 & 3138 & 5626 \\
\hline & $L(1.2)$ & 2.5 & $\mathrm{P}$ & 22.5 & 1.19 & 3362 & 4000 \\
\hline & & & 0 & 14.9 & 0.085 & 2465 & 210 \\
\hline & & & $B-L$ & 22.8 & 4.88 & 3810 & 18574 \\
\hline & SL (1.1) & 1.5 & B-L & 27.2 & 7.58 & 4931 & 37378 \\
\hline & $\mathrm{L}(1.2)$ & 2.5 & $\mathrm{O}$ & 5.7 & 0.212 & 672.3 & 142.5 \\
\hline & & & B-L & 19.3 & 15.4 & 3138 & 48260 \\
\hline \multirow[t]{2}{*}{ Emameh } & $\mathrm{L}(1.2)$ & 2.5 & $P$ & 29.9 & 5.81 & 4483 & 26042 \\
\hline & & & 0 & 26.8 & 0.472 & 4706 & 2221 \\
\hline
\end{tabular}


Table 5. Contd.

\begin{tabular}{|c|c|c|c|c|c|c|c|}
\hline & & & $B-L$ & 24.0 & 12.3 & 4706 & 57969 \\
\hline & \multirow[t]{2}{*}{ SL (4.1) } & 5.5 & 0 & 8.9 & 2.18 & 1009 & 2197 \\
\hline & & & B-L & 13.1 & 0.711 & 1726 & 12267 \\
\hline & \multirow[t]{2}{*}{ SL (1.1) } & 2.5 & 0 & 16.1 & 0.073 & 2465 & 180.0 \\
\hline & & & B-L & 22.2 & 8.35 & 3586 & 29952 \\
\hline & \multirow[t]{2}{*}{$L(1.2)$} & 2.5 & $P$ & 26.6 & 2.82 & 4034 & 11380 \\
\hline & & & B-L & 22.2 & 4.38 & 4482 & 19641 \\
\hline \multirow[t]{13}{*}{ Afjeh } & \multirow[t]{3}{*}{$L(1.2)$} & 2.5 & 0 & 22.0 & 0.307 & 3586 & 1101 \\
\hline & & & $P$ & 29.3 & 3.08 & 4258 & 13128 \\
\hline & & & B-L & 25.3 & 15.0 & 4931 & 73894 \\
\hline & \multirow[t]{2}{*}{$\mathrm{SL}(3.1)$} & 5.5 & 0 & 12.7 & 0.27 & 1569 & 423.6 \\
\hline & & & B-L & 18.2 & 1.37 & 2465 & 3375 \\
\hline & \multirow[t]{2}{*}{ SL (4.1) } & 5.5 & 0 & 10.2 & 1.68 & 1188 & 1990 \\
\hline & & & B-L & 8.7 & 1.39 & 1031 & 1427 \\
\hline & \multirow[t]{2}{*}{$\mathrm{CL}(2.2)$} & 2.5 & B-L & 12.5 & 4.53 & 1031 & 4672 \\
\hline & & & 0 & 11.3 & 0.984 & 874.1 & 860.1 \\
\hline & \multirow[t]{2}{*}{$\mathrm{CL}(2.2)$} & 2.5 & B-L & 14.7 & 1.68 & 1233 & 2075 \\
\hline & & & 0 & 10.6 & 0.09 & 806.8 & 72.61 \\
\hline & \multirow[t]{2}{*}{ SL (3.1) } & 5.5 & 0 & 2.30 & 0.34 & 150.2 & 51.50 \\
\hline & & & $B-L$ & 2.00 & 0.336 & 145.7 & 48.95 \\
\hline \multirow[t]{12}{*}{ Kond } & \multirow[t]{3}{*}{$L(1.2)$} & 2.5 & $P$ & 31.3 & 6.46 & 4931 & 31827 \\
\hline & & & 0 & 19.5 & 0.094 & 3362 & 316.00 \\
\hline & & & B-L & 29.4 & 14.4 & 6051 & 87166 \\
\hline & \multirow[t]{2}{*}{ SL (4.1) } & 5.5 & 0 & 11.0 & 1.24 & 1390 & 1716 \\
\hline & & & B-L & 13.5 & 4.01 & 1860. & 7465 \\
\hline & SL (3.1) & 5.5 & B-L & 22.1 & 1.38 & 3138 & 4330 \\
\hline & \multirow[t]{2}{*}{$L(1.3)$} & 5.5 & 0 & 12.6 & 2.21 & 2062 & 4563 \\
\hline & & & B-L & 13.5 & 8.5 & 2241 & 19050 \\
\hline & $\mathrm{CL}(2.2)$ & 2.5 & B-L & 15.1 & 3.09 & 1345 & 4155 \\
\hline & \multirow[t]{3}{*}{$L(1.2)$} & 2.5 & 0 & 12.0 & 0.536 & 1927 & 1033 \\
\hline & & & $P$ & 22.8 & 1.93 & 3586 & 6921 \\
\hline & & & B-L & 21.5 & 13.4 & 4482 & 59929 \\
\hline
\end{tabular}

$\mathrm{SL}=$ Sandy loam, $\mathrm{L}=\mathrm{Loamy}, \mathrm{CL}=$ Clay loam; F= Farm land, Barren land, Pasture=P, Orchard=O.

Table 6. The results of calculated sediment load by the model and measurement.

\begin{tabular}{|c|c|c|c|c|c|c|}
\hline Station & $\begin{array}{l}\text { Soil loss } \\
\text { (ton/year) }\end{array}$ & $\begin{array}{l}\text { SDR } \\
(\%)\end{array}$ & $\begin{array}{c}\text { Estimated total } \\
\text { sediments (ton/year) }\end{array}$ & $\begin{array}{c}\text { Calculated suspended } \\
\text { load (ton/year) }\end{array}$ & $\begin{array}{c}\text { Actual suspended } \\
\text { load (ton/year) }\end{array}$ & $\begin{array}{c}\text { Model precision } \\
(\%)\end{array}$ \\
\hline Roodak & 1524 & 16 & 243.8 & 187.6 & 216.0 & 86.8 \\
\hline Najarkola & 228.5 & 24.7 & 56.49 & 43.38 & 50.09 & 86 \\
\hline Naroon & 103.1 & 28 & 288.9 & 22.22 & 40.64 & $55^{*}$ \\
\hline
\end{tabular}

*In Afjeh because the lack of actual suspended load data, this number (40637) in the above table is not a good indicator for this parameter. Therefore the obtained precision is not a suitable value for model in Afjeh basin.

The change of land-uses and estimating the erosion variation

Now, with the change of the land-uses in the basin according to the Figure 7, erosion modeling was performed. The results of running the model again are presented in Table 8. The compared results are presented in Table 9. 


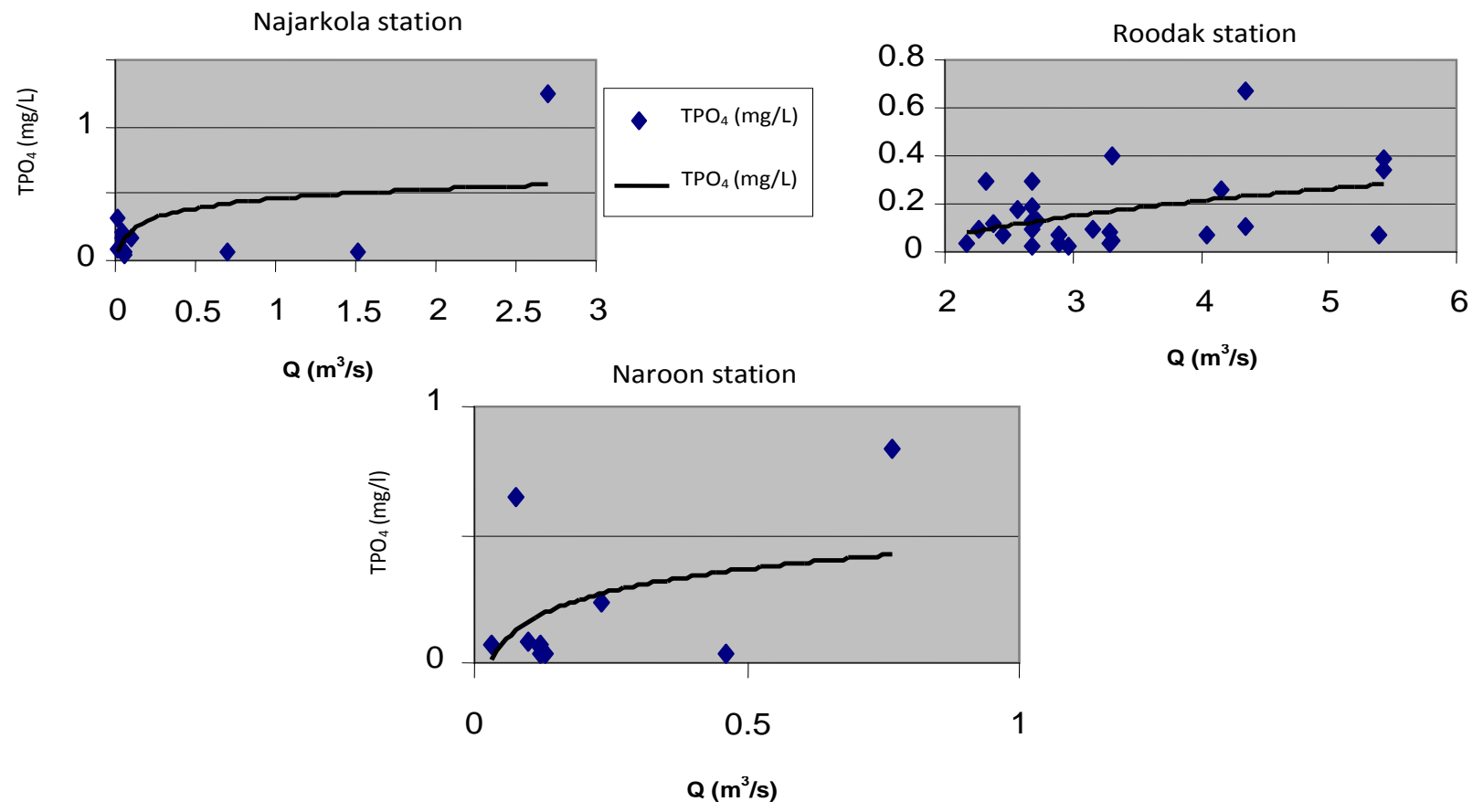

Figure 6. Variation of total phosphate $\left(\mathrm{TPO}_{4}\right)$ and river discharge $(\mathrm{Q})$ at the Najarkola, Roodak and Naroon stations.

Table 7. The amounts of particulate phosphorus due to erosion in the stations.

\begin{tabular}{lcc}
\hline Basin & $\begin{array}{c}\text { The particulate phosphorus } \\
\text { resulted from erosion (ton/year) }\end{array}$ & $\begin{array}{c}\text { The amount of phosphorus in the } \\
\text { suspended sediment load (g/ton) }\end{array}$ \\
\hline Roodak & 12.10 & 56.21 \\
Kond & 1.587 & 31.7 \\
Afjeh & 0.295 & $7.3^{*}$ \\
\hline
\end{tabular}

* In Afjeh because the lack of actual suspended load data, this number in the above table is not a good indicator for this parameter.

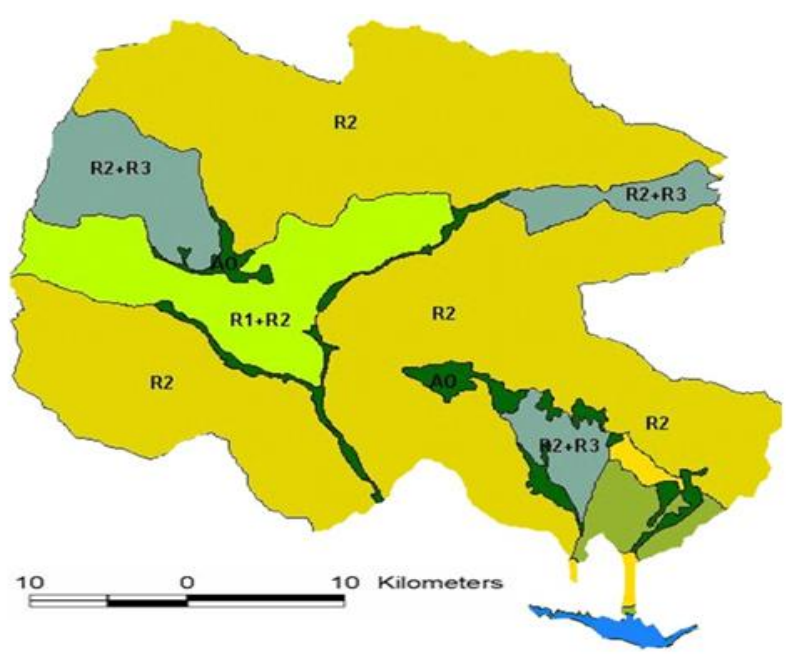

Gardens and agricultural lands Dryland Agriculture

Poor pasture and Semi-intensive grazing

Semi-intensive grazing

Semi-intensive grazing and agricultural lands Semi-intensive grazing and Dense grassland lake

Figure 7. The map of present land use. 
Table 8. The result of erosion modeling in the basin with new land.

\begin{tabular}{|c|c|c|c|c|c|c|}
\hline Basin & Area & $\begin{array}{l}\text { The recommended } \\
\text { land-use }\end{array}$ & Slope (degree) & Area $\left(\mathrm{km}^{2}\right)$ & $\begin{array}{c}\text { Erosion } \\
\text { (ton } / \mathrm{km}^{2} / \text { year) } \\
\end{array}$ & $\begin{array}{c}\begin{array}{c}\text { Erosion } \\
\text { (ton/year) }\end{array} \\
\end{array}$ \\
\hline \multirow{5}{*}{ Garmabdar } & 1.1 & $\mathrm{R} 2$ & 25.98 & 78.90 & 1569 & 123700 \\
\hline & 1.3 & $\mathrm{R} 2+\mathrm{R} 3$ & 22.39 & 14.60 & 538 & 7864 \\
\hline & 4.1 & $\mathrm{AO}$ & 15.58 & 2.28 & 1569 & 3773 \\
\hline & 1.4 & $\mathrm{R} 1+\mathrm{R} 2$ & 24.32 & 19.00 & 2465 & 46840 \\
\hline & 1.2 & $\mathrm{R} 2$ & 25.58 & 42.90 & 1726 & 73980 \\
\hline \multirow{5}{*}{ Meygoon } & 1.1 & $\mathrm{R} 2$ & 25.42 & 31.90 & 1524 & 48554 \\
\hline & 1.2 & $\mathrm{R} 2$ & 21.10 & 8.73 & 1345 & 11739 \\
\hline & 1.3 & $\mathrm{R} 2+\mathrm{R} 3$ & 24.93 & 19.00 & 650 & 12348 \\
\hline & 1.4 & $\mathrm{R} 1+\mathrm{R} 2$ & 22.65 & 13.80 & 2174 & 30043 \\
\hline & 4.1 & $\mathrm{AO}$ & 17.43 & 3.19 & 1905 & 6077 \\
\hline \multirow{4}{*}{ Ahar } & 1.2 & $\mathrm{R} 2$ & 24.15 & 57.11 & 1905 & 108793 \\
\hline & 1.3 & $\mathrm{R} 2+\mathrm{R} 3$ & 28.08 & 10.15 & 1053 & 10691 \\
\hline & 1.4 & $\mathrm{R} 1+\mathrm{R} 2$ & 25.22 & 24.77 & 2689 & 66616 \\
\hline & 4.1 & $\mathrm{AO}$ & 21.28 & 2.09 & 2465 & 5457 \\
\hline \multirow{5}{*}{ Roodak } & 1.1 & $\mathrm{R} 2$ & 29.10 & 7.55 & 1927 & 14556 \\
\hline & $1.2 u p$ & $\mathrm{R} 2$ & 23.03 & 6.15 & 1905 & 11721 \\
\hline & 1.2down & $\mathrm{R} 2$ & 21.18 & 15.60 & 1726 & 26921 \\
\hline & 1.4 & $\mathrm{R} 1+\mathrm{R} 2$ & 22.50 & 5.41 & 2465 & 13344 \\
\hline & 4.1 & $\mathrm{AO}$ & 20.26 & 2.08 & 2465 & 5428 \\
\hline \multirow{4}{*}{ Emameh } & 1.1 & $\mathrm{R} 2$ & 23.73 & 8.46 & 1793 & 15161 \\
\hline & 1.2up & $\mathrm{R} 2$ & 26.90 & 18.61 & 2241 & 41708 \\
\hline & 1.2down & $\mathrm{R} 2$ & 24.97 & 7.15 & 2107 & 15054 \\
\hline & 4.1 & $\mathrm{AO}$ & 12.25 & 2.89 & 1277 & 3688 \\
\hline \multirow{6}{*}{ Kond } & 1.2up & $\mathrm{R} 2$ & 29.78 & 20.96 & 2465 & 51672 \\
\hline & 1.2down & $\mathrm{R} 2$ & 21.33 & 15.86 & 1748 & 27725 \\
\hline & 4.1 & $\mathrm{AO}$ & 12.88 & 5.25 & 1412 & 7413 \\
\hline & 1.3 & $\mathrm{R} 2+\mathrm{R} 3$ & 13.25 & 10.71 & 426 & 4562 \\
\hline & 3.1 & DF & 21.93 & 1.37 & 538 & 739 \\
\hline & 2.2 & $\mathrm{R} 2+\mathrm{F}$ & 15.10 & 3.06 & 359 & 1098 \\
\hline \multirow{6}{*}{ Afjeh } & 1.2 & $\mathrm{R} 2$ & 25.91 & 18.37 & 1121 & 20582 \\
\hline & 4.1 & $\mathrm{AO}$ & 9.43 & 3.06 & 874 & 2674 \\
\hline & 2.2up & $\mathrm{R} 2+\mathrm{F}$ & 12.02 & 5.53 & 269 & 1488 \\
\hline & 2.2down & $\mathrm{R} 2+\mathrm{F}$ & 14.55 & 1.75 & 336 & 588 \\
\hline & 3.1up & DF & 16.72 & 1.65 & 381 & 627 \\
\hline & 3.1down & DF & 2.49 & 0.679 & 29.1 & 19.8 \\
\hline
\end{tabular}

Table 9. The comparison of the results of erosion modeling in the present condition with the suggested land-use conditions.

\begin{tabular}{lccccc}
\hline Basin & $\begin{array}{c}\text { The erosion with } \\
\text { new land-use } \\
\text { (ton/year) }\end{array}$ & $\begin{array}{c}\text { The erosion with } \\
\text { the former land- } \\
\text { use (ton/year) }\end{array}$ & $\begin{array}{c}\text { The calculated } \\
\text { suspended load } \\
\text { with new land-use } \\
\text { (ton/year) }\end{array}$ & $\begin{array}{c}\text { The } \\
\text { percentage of } \\
\text { erosion } \\
\text { reduction }\end{array}$ & $\begin{array}{c}\text { The particulate } \\
\text { phosphorus entering } \\
\text { after the new land-use } \\
\text { (ton/year) }\end{array}$ \\
\hline Roodak & 703.5 & 1524 & 86.58 & 54 & 4.87 \\
Kond & 93.21 & 228.5 & 17.71 & 59 & 0.56 \\
Afjeh & 25.98 & 103.1 & 5.595 & 75 & 0.041 \\
\hline
\end{tabular}




\section{Conclusion}

By comparing the results of sediment load calculated by the model with the actual values, the precision of the model in estimating the erosion and the sediment yield for the upstream basins of Roodak, Kond and Afjeh was respectively of $86.8,86$ and $55 \%$, although depend on the percentage assumed valid for SDR. These results show the suitable precision of the model for Roodak and Kond basins (if in the basin of Afjeh, more measuring data for suspended load could be gathered, the more precise outputs of the model can be obtained in this basin).

The results show that the use of vegetation to areas without coverage and use of appropriate vegetation density appropriate land, the amount of erosion and the phosphorus load are reduced considerably. As a result, by using the suggested methods of land-uses for the basins discussed so far, the degree of erosion reduction in the upper basins of Roodak is about $54 \%$, for Kond basin is about $59 \%$ and in the basin of Afjeh is about $75 \%$.

\section{Conflict of Interests}

The author(s) have not declared any conflict of interests.

\section{REFERENCES}

Yazidhi B (2003). A comparative study of soil erosion modeling in Lom Kao-Phetchabun, Thailand. International institute for geo-information science and earth observation enschede, the Netherland.

Cox C, Madramootoo C (1998). Application of geographic information systems in watershed management planning in ST. Lucia. Ministry of Agriculture, Forestry, Fisheries and the Environment.

Desmet PJJ, Govers G (1996). A GIS procedure for automatically calculating the USLE LS factor on topographically complex landscape units. J. Soil Water Conserv. 51(5):427-433.

Foster GR (2003). "User's Reference Guide, RUSLE2, Oxford, Mississippi.

Maleki M, Ahmadee H, Jafaree M, Ghoddousee J, Azarniuvand H, Mosayyebee M (2011). Quantitative modeling of water erosion using Analytic hierarchy process (Latian dam watershed). Fourth National Conference sediment Department of Watershed Management Engineering College of Natural Resources Tarbiat Modarres University.

Blonn P (2001). A GIS-based model of diffuse pollution in the oak creek and menomonee river watersheds. project sponsored by the USEPA Grant No. R82-5759 to Marquette University from the USEPA/NSF/USDA STAR Watershed Program.

Poorabdollah M (2007). Comparison of models RUSLE and SWAT to estimate Erosions in the sub-basin Amameh Thesis Sharif University.

Sadeghi H (1994). Evaluate the accuracy and efficiency of computer models in estimating runoff and sediment II SEDIMOT. Thesis Tarbiat Modarres University.

Tahmasebipoor N (1995). Evaluate the erosion model M.P.S.I.A.C. Thesis Tarbiat Modarres University.

Tehran's agricultural organization (2002a). Meteorology and climatology of Latian Dam watershed.
Tehran's agricultural organization (2002b). Land cover studies of Latian Dam watershed.

Water and Energy center of Sharif University (2003a). Environmental studies of Latian Dam watershed. 2003.

Water and Energy center of Sharif University (2003b). Soil studies of Latian Dam watershed. 2003.

Wischmeier WH, Johnson CB, Cross BW (1971). A soil erodibility nomograph for farmland and construction sites. J. soil water conservat. 26(5):189-193.

Wischmeier WH, Smith DD (1978). Predicting Rainfall erosion losses-A guide to conservation planning. The USDA agricultural handbook No.537. 